\title{
EFEKTIFITAS ANTARA PERAWATAN LUKA DENGAN MENGGUNAKAN NaCl 0,9\% DAN BETADIN TERHADAP PROSES PENYEMBUHAN LUKA POST OPERASI
}

Sri Lestari*Kunidah**

\begin{abstract}
ABSTRAK
Penyembuhan luka merupakan suatu proses yang kompleks karena berbagai kegiatan bio-seluler, bio-kimia terjadi berkesinambungan. Sifat penyembuhan pada semua luka sama, dengan variasinya bergantung pada lokasi, keparahan, dan luasnya cedera. Tujuan penelitian ini untuk mengetahui efektifitas antara perawatan luka menggunakan $\mathrm{NaCl}$ 0,9\% dengan betadin terhadap proses penyembuhan luka post operasi pada pasien sectio caesarea. Penelitian ini merupakan jenis penelitian Quaisy Experimen. Dengan populasi seluruh pasien perawatan luka post operasi sectio caesarea yaitu 26, dan menggunakan teknik sampel purposive sampling dengan jumlah 13 responden setiap kelompok. Penelitian ini dilakukan di Rumah Sakit Ciremai Kota Cirebon. Hasil penelitian ini adalah perawatan luka post operasi sectio caesarea menggunakan $\mathrm{NaCl} 0,9 \%$ sebanyak 13 responden dengan proses penyembuhan luka $\leq 3$ hari di dapatkan rata-rata 7,07. Dan hasil bivariate menunjukkan bahwa ada perbedaan antara efektifitas proses penyembuhan luka pada perawatan luka pasien post operasi sectio caesarea menggunakan $\mathrm{NaCl} 0,9 \%$ dengan nilai $p$ value $=0,000<(\mathrm{a}=0,05)$.
\end{abstract}

Kata kunci : Proses penyembuhan luka, perawatan luka, $\mathrm{NaCl} 0,9 \%$, Betadin

\begin{abstract}
Wound healing is a complex process because of the various activies of bio-chemical, bio-cell occurs continuosly. Wound healing properties on the all the same, with variations depending on the location, saverity, and the extent of the injury. The purpose of this reseach was to determine the effectiveness of wound care using $\mathrm{NaCl} 0,9 \%$ with using betadin to wound healing process post operation on patients sectio caesarea. This research is a kind of the quaisy experimental. With a population of whole patients wound care post operatition sectio caesarea which is 26 , and using the tecnique of purposive sampling with a total of 13 respondents per-group. The research was conducted at the ciremai hospital of cirebon city.

The results of this research are wound care post operation sectio caesarea using $\mathrm{NaCl} 0,9 \%$ as much 13 respondents with the healing process of wound $\leq 3$ days obtained of average 7,07. Bivariate and result showed the there is between the effectiveness of the process of wound healing in wound care patient post operation sectio caesarea using $\mathrm{NaCl} 0,9 \%$ with a value $\mathrm{p}=0,000<(\mathrm{a}=0,05)$.
\end{abstract}

Keywords : The process of wound healing, wound care, $\mathrm{NaCl} 0,9 \%$, betadin

\footnotetext{
* Staf Pengajar Program Studi S1 Keperawatan STIKes Cirebon

** Alumni PSIK STIKes Cirebon Lulus Tahun 2015
} 


\section{PENDAHULUAN}

Dewasa ini perawatan luka mengalami perkembangan yang sangat pesat terutama dalam dua dekade terakhir ini. Teknologi dalam bidang kesehatan juga memberikan konstribusi untuk menunjang praktek perawatan luka ini. Disamping itu manajemen perawatan luka ini berkaitan dengan perubahan profil pasien, dimana pasien dengan kondisi penyakit degeneratif dan kelainan metabolik semakin banyak ditemukan. Kondisi tersebut biasanya sering menyertai kekomplekan suatu luka dimana perawatan yang tepat diperlukan agar proses penyembuhan bisa tercapai dengan optimal. ${ }^{1}$

Dengan demikian, perawat dituntut untuk mempunyai pengetahuan dan keterampilan yang adekuat terkait dengan proses perawatan luka yang dimulai dari pengkajian yang komprehensif, perencanaan intervensi yang tepat, implementasi tindakan, evaluasi hasil yang ditemukan selama perawatan serta dokumentasi hasil sistematis. Manajemen perawatan luka modern sangat mengedepankan hal tersebut. Hal ini ditunjang dengan semakin banyaknya motivasi terbaru dalam perkembangan produk-produk yang bisa dipakai dalam merawat luka. Dalam hal ini, perawat dituntut untuk memahami produk-produk tersebut dengan baik sebagai bagian dari proses pengambilan keputusan sesuai dengan kebutuhan pasien. ${ }^{2}$

Secara umum luka merupakan masalah yang tidak dapat dihindari dalam kehidupan manusia, baik itu disengaja seperti karena luka operasi yang direncanakan atau yang tidak disengaja yang disebabkan oleh karena kecelakaan ataupun oleh karena suatu penyakit. ${ }^{3}$

Sectio caesarea adalah sebuah bentuk melahirkan anak dengan melakukan sebuah irisan pembedahan yang menembus abdomen seorang ibu (laparotomi) dan uterus (hiskotomi) untuk mengeluarkan satu bayi atau lebih. ${ }^{4}$

Tindakan sectio caesarea merupakan pilihan utama bagi tenaga medis untuk menyelamatkan ibu dan janin. ${ }^{5}$

World Health Organization (WHO) pada tahun 2012 menetapkan standar rata-rata sectio caesarea di sebuah Negara adalah sekitar 5-15\% per 1000 kelahiran di dunia. Rumah Sakit pemerintah kira - kira $11 \%$ sementara Rumah Sakit swasta bisa lebih dari 30\%. Menurut WHO peningkatan persalinan dengan section caesarea di seluruh negara selama tahun 2011 - 2012 yaitu 110.000 per kelahiran di seluruh Asia. Di Indonesia angka kejadian sectio caesarea mengalami peningkatan pada tahun 2009 jumlah ibu bersalin dengan sectio caesarea 42,22\%, tahun 2010 sebesar 44,19\%, tahun 2011 sebesar 47,13\%, tahun 2012 sebesar 45,87\%, dan tahun 2013 belum terdapat data yang signifikan. Survei Nasional pada tahun 2012, 921.000 persalinan dengan sectio caesarea dari 4.039.000 persalinan atau sekitar $22,8 \%$ dari seluruh persalinan. ${ }^{6}$

Dari hasil penelitian yang dilakukan sebelumnya oleh Feri Supardi dengan judul perbedaan hari rawat pada pasien luka bersih menggunakan betadin dengan perawatan luka bersih menggunakan $\mathrm{NaCl}$ 0,9\% di Puskesmas Tanjung Siang Kabupaten Subang tahun 2012 adalah 46,9 responden dengan lama hari rawat $<3$ hari, dan 53,1 responden dengan lama hari rawat $>3$ hari. Terdapat perbedaan yang signifikan rata-rata lama hari rawat pada perawatan luka bersih dengan menggunakan larutan $\mathrm{NaCl}$ 0,9\% dan betadin di Puskesmas Tanjung Siang Subang. ${ }^{7}$

Hasil penelitian yang dilakukan sebelumnya oleh Siska Febrianti dengan judul efektifitas antara perawatan luka dengan menggunakan kompres povidone iodine $10 \%$ dan nacl $0,9 \%$ terhadap proses penyembuhan luka pada pasien post operasi prostatektomi di ruang bedah RSUD'45 Kuningan adalah pada kelompok perawatan luka dengan menggunakan povidone iodine $10 \%$ didapatkan rata-rata proses penyembuhan luka untuk fase inflamasi terjadi selama 5 hari dan fase ploriferasi terjadi pada hari ke-6. Dan pada kelompok perawatan luka dengan menggunakan $\mathrm{NaCl} 0,9 \%$ didapatkan rata-rata proses penyembuhan luka untuk fase inflamasi terjadi selama 5,8 hari dan fase ploriferasi terjadi pada hari ke-7. Analisa data 
untuk menguji hipotesis juga dapat dilihat dari nilai hasil uji case control dengan hasil nilai 1,006, berarti didapatkan keputusan bahwa povidone iodine $10 \%$ dapat meningkatkan proses penyembuhan luka lebih cepat 1,006 hari dari $\mathrm{NaCl} 0,9 \% .^{8}$

Penelitian ini bertujuan untuk mengetahui efektifitas perawatan luka dengan menggunakan $\mathrm{NaCl} 0,9 \%$ dan betadin terhadap proses penyembuhan luka pada pasien post operasi sectio caesarea di Ruang Widya Rumah Sakit Ciremai Kota Cirebon.

\section{METODE PENELITIAN}

Penelitian ini merupakan jenis penelitian quasy experiment dengan rancangan yang digunakan adalah non equivalent control group design dimana sampel pada penelitian ini observasi terlebih dahulu sebelum diberi perlakuan menggunakan betadin dan $\mathrm{NaCl} 0,9 \% .{ }^{9}$ Variabel bebas dalam penelitian ini adalah perawatan luka post operasi sectio caesarea menggunakan $\mathrm{NaCl}$ 0,9\% dan betadin. Sedangkan variabel terikat dalam penelitian ini adalah proses penyembuhan luka post operasi sectio caesarea. Populasi dalam penelitian ini adalah semua pasien dengan luka post operasi sectio caesarea yang berada di Rumah Sakit Ciremai Kota Cirebon pada bulan Januari 2015 yaitu sebanyak 26 pasien. Teknik sampel yang digunakan adalah non probability sampling yaitu purposive sampling Jumlah sampel dalam penelitian ini adalah masing-masing 13 pasien post operasi sectio caesarea (kelompok perawatan luka yang menggunakan betadin dengan kelompok perawatan luka yang menggunakan $\mathrm{NaCl} 0,9 \%$ ). Instrumen penelitian sebagai alat pengumpulan data yang digunakan adalah observasi pengamatan dalam bentuk check-list. Check-list yang akan digunakan dalam penelitian ini berbentuk SPO. Analisis univariat menggunakan distribusi frekuensi. Analisa bivariat dilakukan dengan uji statistik Mann Whitney U Test.

\section{HASIL PENELITIAN}

\section{Proses Penyembuhan Luka}

Tabel 1. Distribusi frekuensi proses penyembuhan luka di Rumah Sakit Ciremai Kota Cirebon Tahun 2015

\begin{tabular}{lcccc}
\hline Proses Penyembuhan Luka & \multicolumn{2}{c}{$\mathrm{NaCl} 0,9 \%$} & \multicolumn{3}{c}{ Betadin } \\
\cline { 2 - 5 } & $\mathrm{N}$ & $\%$ & $\mathrm{~N}$ & $\%$ \\
\hline$\leq 3$ Hari & 13 & 100 & 0 & 0 \\
$>$ 3 hari & 0 & 0 & 13 & 100 \\
\hline Jumlah & 13 & 100 & 13 & 100 \\
\hline
\end{tabular}

Berdasarkan tabel 1 dapat diuraikan proses penyembuhan luka $\leq 3$ hari yang menggunakan $\mathrm{NaCl} 0,9 \%$ yaitu sebanyak 13 responden (100\%), dan proses penyembuhan luka $>3$ hari yang menggunakan betadin yaitu sebanyak 13 responden (100\%).

\section{Efektifitas Proses Penyembuhan Luka}

Tabel 2. Efektifitas proses penyembuhan luka di Rumah Sakit Ciremai Kota Cirebon Tahun 2015

\begin{tabular}{|c|c|c|c|c|c|}
\hline \multirow[t]{2}{*}{ Proses Penyembuhan Luka } & \multicolumn{2}{|c|}{$\mathrm{NaCl} 0,9 \%$} & \multicolumn{2}{|c|}{ Betadin } & $P$ value \\
\hline & $\mathrm{N}$ & $\%$ & $\mathrm{~N}$ & $\%$ & \multirow[b]{3}{*}{0,000} \\
\hline$\leq 3$ Hari & 13 & 100 & 0 & 0 & \\
\hline$>3$ hari & 0 & 0 & 13 & 100 & \\
\hline Jumlah & 13 & 100 & 13 & 100 & \\
\hline
\end{tabular}


Uji statistik normalitas data proses penyembuhan luka pada pasien perawatan luka post operasi sectio caesarea menggunakan $\mathrm{NaCl} 0,9 \%$ dengan perawatan luka post operasi sectio caesarea menggunakan Betadin. Yaitu di dapatkan hasil statistik 0,337 dengan standar deviasi 26 dan nilai pvalue $=0,000<(\mathrm{a}=0,05)$ maka distribusi data tersebut dikatakan tidak normal. Jadi proses penyembuhan luka pada pasien perawatan luka post operasi sectio caesarea menggunakan larutan $\mathrm{NaCl} 0,9 \%$ dengan perawatan luka post operasi sectio caesarea menggunakan betadin dilakukan uji statistik menggunakan Mann Whitney. Dengan didapatkan hasil proses penyembuhan $\leq 3$ hari dengan jumlah respoden 13 pasien rata-rata 7,07. Sedangkan proses penyembuhan $>3$ hari dengan jumlah responden 13 pasien rata-rata 20,00. Hasil uji statistik tersebut didapatkan nilai pvalue $=0,000<(\mathrm{a}=0,05)$ berarti terlihat ada perbedaan antara proses penyembuhan luka pada perawatan luka pasien post operasi sectio caesarea menggunakan larutan $\mathrm{NaCl} 0,9 \%$ dengan perawatan luka pada post operasi sectio caesarea menggunakan larutan betadin di Rumah Sakit Ciremai Kota Cirebon.

\section{PEMBAHASAN}

\section{Distribusi frekuensi responden berdasarkan proses penyembuhan luka pada pasien sectio caesarea}

Berdasarkan hasil perhitungan dapat disimpulkan bahwa proses penyembuhan luka $\leq$ 3 hari sebanyak 13 responden (100\%) dan > 3 hari sebanyak 13 responden (100\%). Ada banyak faktor yang mempengaruhi proses penyembuhan luka yaitu : usia, infeksi, hipovolemia, hematoma, benda asing, iskemia, diabetes, dan pengobatan. Tubuh secara normal akan berespon terhadap cedera dengan jalan "proses peradangan "yang dikarakteristikkan dengan lima tanda utama : bengkak (swealling), kemerahan (redness), panas (heat), nyeri (pain), dan kerusakan fungsi (impaired function). ${ }^{10}$

Proses penyembuhan mencakup beberapa fase yaitu: ${ }^{10}$

\section{Fase Maturasi}

Menyempurnakan terbentuknya jaringan baru menjadi jaringan penyembuhan yang kuat dan bermutu.

\section{Fase Destruktif}

Fase destruktif merupakan fase pembersihan jaringan yang mati dan yang mengalami devitalisasi oleh leukosit polimorfonuklear dan makrofag. Pembersihan terhadap jaringan mati yang mengalami devitalisasi dan bakteri oleh polimorf dan makrofag.

\section{Fase Proliferatif}

Proses kegiatan seluler yang penting pada fase ini adalah memperbaiki dan menyembuhkan luka dan ditandai dengan proliferasi sel.

\section{Fase Inflamasi}

Fase inflamasi adalah adanya respon vaskuler dan seluler yang terjadi akibat perlukaan yang terjadi pada jaringan lunak. Tujuan yang hendak dicapai adalah menghentikan perdarahan dan membersihkan area luka dari benda asing, sel-sel mati dan bakteri untuk mempersiapkan dimulainya proses penyembuhan.

\section{Proses penyembuhan luka pada pasien perawatan luka post operasi sectio caesarea menggunakan $\mathrm{NaCl} 0,9 \%$ dengan betadin}

Berdasarkan hasil perhitungan dapat disimpulkan bahwa proses penyembuhan luka pada pasien perawatan luka post operasi sectio caesarea menggunakan $\mathrm{NaCl} 0,9 \%$ dengan menggunakan betadin, diketahui bahwa proses penyembuhan $\leq 3$ hari dengan jumlah respoden 13 pasien, rata-rata 7,07. Sedangkan proses penyembuhan $>3$ hari dengan jumlah responden 13 pasien, rata-rata 20,00. Hasil uji statistik mann whitney didapatkan nilai pvalue $=0,000<(\mathrm{a}=0,05)$ maka $\mathrm{H}_{1}$ diterima, berarti terlihat ada perbedaan yang signifikan proses 
penyembuhan luka pada pasien perawatan luka post operasi sectio caesarea menggunakan $\mathrm{NaCl}$ 0,9\% dengan menggunakan betadin di Rumah Sakit Ciremai Kota Cirebon. Hal ini sesuai dengan teori yang menyebutkan bahwa sodium klorida adalah larutan fisiologis yang ada di seluruh tubuh karena antiseptik ini tidak ada reaksi hipersensitivitas dari sodium klorida. Normal saline aman digunakan untuk kondisi apapun. ${ }^{11}$

Sodium klorida tersedia dalam beberapa konsentrasi, yang paling sering adalah sodium klorida $0,9 \%$. Ini adalah konsentrasi normal dari sodium klorida dan untuk antiseptik ini sodium klorida disebut juga normal saline. ${ }^{11}$ Merupakan larutan isotonis aman untuk tubuh, tidak iritan, melindungi granulasi jaringan dari kondisi kering, menjaga kelembaban sekitar luka dan membantu luka menjalani proses penyembuhan serta mudah didapat dan harga antiseptik lebih murah. ${ }^{12}$

Sedangkan iodine adalah elemen non metalik yang tersedia dalam bentuk garam yang dikombinasi dengan bahan lain. Walaupun iodine bahan non metalik iodine berwarna hitam kebiru-biruan dan tampak kilau metalik dan mempunyai bau yang khas iodine hanya larut sedikit di dalam air, tetapi dapat larut secara keseluruhan di dalam alkohol sehingga akan tampak lebih encer ketika dimasukkan ke dalam alkohol. Iodine aktif melawan spora yang tergantung dari konsentrasi dan waktu pemberian. Larutan ini akan melepaskan iodium anorganik bila kontak dengan kulit atau selaput lendir sehingga cocok untuk perawatan luka kotor dan terinfeksi bakteri gram positif dan negatif, spora, jamur, dan protozoa. ${ }^{11}$

Betadin atau iodine digunakan untuk desinfektan sebelum dan setelah operasi dengan tujuan untuk mencegah timbulnya infeksi pada luka. ${ }^{13}$ Povidine iodine dapat membunuh semua patogen yang penting, bahkan dapat membunuh spora dimana spora merupakan salah satu bentuk dari mikroorganisme yang paling sulit dibunuh. Povidine oidine dapat menyebabkan sedikit iritasi kulit dan menimbulkan reaksi alergi, serta sering menyebabkan dermatitis kontak iritan. ${ }^{14}$

Penyembuhan luka merupakan suatu proses yang kompleks karena berbagai kegiatan bio-seluler, bio-kimia terjadi berkesinambungan. Penggabungan respon vaskuler, aktivitas seluler dan terbentuknya bahan kimia sebagai substansi mediator didaerah luka merupakan komponen yang saling terkait pada proses penyembuhan luka. Besarnya perbedaan mengenai penelitian dasar mekanisme penyembuhan luka dan aplikasi klinik saat ini telah dapat diperkecil dengan pemahamam dan penelitian yang berhubungan dengan proses penyembuhan luka dan pemakaian bahan pengobatan yang telah berhasil memberikan kesembuhan. ${ }^{10}$

Penyembuhan luka melibatkan integrasi proses fisiologis. Sifat penyembuhan pada semua luka sama, dengan variasinya bergantung pada lokasi, keparahan, dan luasnya cedera. Kemampuan sel dan jaringan melakukan regenerasi atau kembali ke struktur normal melalui pertumbuhan sel juga mempengaruhi penyembuhan luka. Sel hati, tubulus ginjal dan neuron pada sistem saraf pusat mengalami regenerasi yang lambat atau tidak beregenerasi sama sekali. $^{10}$

\section{SIMPULAN}

Dari hasil penelitian yang telah dilakukan dapat diambil kesimpulan sebagai berikut:

1. Distribusi responden berdasarkan perawatan luka, sebanyak 13 responden perawatan luka post operasi sectio caesarea menggunakan $\mathrm{NaCl} 0,9 \%$, dan sebanyak 13 responden perawatan luka post operasi sectio caesarea menggunakan betadin.

2. Berdasarkan proses penyembuhan luka, sebanyak 13 responden dengan proses penyembuhan luka $\leq 3$ hari, dan sebanyak 13 responden dengan proses penyembuhan luka > 3 hari. 
3. Ada perbedaan yang signifikan proses penyembuhan luka pada perawatan luka pasien post operasi sectio caesarea menggunakan larutan $\mathrm{NaCl} 0,9 \%$ dengan perawatan luka pada post operasi sectio caesarea menggunakan larutan betadin di Rumah Sakit Ciremai Kota Cirebon dengan nilai pvalue $=0,000<(a=0,05)$.

\section{SARAN}

Berdasarkan kesimpulan diatas, maka dapat diajukan beberapa saran sebagai berikut :

1. Bagi Stikes Cirebon.

Penelitian ini diharapkan memberikan informasi dan gambaran secara nyata bagi stikes cirebon, memperkuat dan mengembangkan teori yang ada serta menambah wawasan ilmu pengetahuan berkenan dengan perawatan luka serta mempertahankan dan meningkatkan mutu pemberian pelayanan kesehatan disamping sebagai pelindung hukum bagi pemberi dan penerima jasa pelayanan keperawatan.

2. Bagi Ilmu keperawatan

Penelitian ini diharapkan bagi pengembangan ilmu keperawatan khususnya tentang perawatan luka post operasi pada pasien sectio caesarea.

3. Bagi Rumah Sakit Ciremai Kota Cirebon.

Penelitian ini diharapkan dapat digunakan sebagai sumber informasi cara perawatan luka bersih post operasi yang lebih efisien sehingga pelayanan keperawatan lebih bermutu dan efektif.

4. Bagi Ruang Widya

Penelitian ini diharapkan dapat digunakan sebagai sumber informasi tata cara melakukan perawatan luka post operasi pada pasien sectio caesarea yang lebih efektif.

5. Bagi peneliti

Penelitian ini diharapkan dapat menjadi bahan masukan dalam melakukan penelitian yang akan datang yang berkaitan dengan perawatan luka bersih post operasi dengan menggunakan metode yang lain.

6. Bagi Perawat

1) Penelitian ini diharapkan dapat menjadi sumber informasi dan bahan masukan cara perawatan luka pada pasien post operasi sectio caesarea yang lebih efektif.

2) Diharapkan menjadi bahan untuk mengajarkan pada pasien cara melakukan perawatan luka post operasi sectio caesarea yang lebih efektif.

7. Bagi Pasien

1) Hasil penelitian ini diharapkan dapat menjadi dasar bagi pasien agar dapat menanggulangi luka sectio caesarea dengan $\mathrm{NaCl} 0,9 \%$.

2) Dengan perawatan luka yang lebih efektif pada pasien, diharapkan akan membantu mempercepat proses penyembuhan luka post operasi sectio caesarea, sehingga dapat mempercepat waktu perawatan luka di rumah sakit.

3) Serta proses penyembuhan luka yang lebih cepat, maka hal tersebut diharapkan dapat memperpendek waktu rawat di rumah sakit, sehingga dapat menurunkan biaya pasien selama dirawat di rumah sakit.

4) Memenuhi kebutuhan nutrisi agar proses penyembuhan berlangsung lebih cepat.

\section{DAFTAR PUSTAKA}

1. Hidayat, A. Aziz Alimul. Pengantar Kebutuhan Dasar Manusia. Jakarta: Salemba Medika; 2006.

2. Morison, Moya J. Manajemen Luka. Jakarta: EGC; 2004.

3. Kevin. Tentang perawatan Luka; [diakses pada tanggal 3 November 2010] Diunduh dari: http://kevinrestu.blogspot.com 
4. Dewi Y., dkk. Operasi Caesar, Pengantar dari A sampai Z. Jakarta: EDSA Mahkota; 2007.

5. Norwitz, E \& Schorge, J. At Glance Obstetri \& Ginekologi. Ed.2: EMS; 2007.

6. Kounteya Sinha. Article Times Of India. [diakses pada tanggal 13 November tahun 2013] Diunduh dari: http://timesofindia.indiatimes.com/

7. Supardi, F. Perbedaan hari rawat pada pasien luka bersih menggunakan betadin dengan perawatan luka menggunakan $\mathrm{NaCl}$ 0,9\% di puskesmas tanjung siang kabupaten subang tahun 2012. Skripsi. Cirebon: Program Studi Ilmu Keperawatan Sekolah Tinggi Ilmu Kesehatan Cirebon; 2012.

8. Febrianti, S. Efektifitas antara perawatan luka dengan menggunakan kompres povidone iodine $10 \%$ dan Nacl 0,9\% terhadap proses penyembuhan luka pada pasien post operasi prostatektomi di ruang bedah RSUD'45 Kuningan. Skripsi. Cirebon: Akademi Keperawatan Muhammadiyah Cirebon; 2011.

9. Nursalam, Siti Pariani. Pendekatan Praktis Metodelogi Keperawatan. Jakarta: CV. Infomedika; 2010.

10. De2wjie. Proses Penyembuhan Luka. [diakses pada tanggal 4 Oktober 2011]. Diunduh dari: http://materipakanwar/prosespenyembuhanluka.mht

11. Lilley \& Aucker. Pharmacology and The Nursing Process. $2^{\text {nd }}$ edition. Mosby; 1999.

12. Afriazenifatma94. Perawatan Luka Operasi. [diakses pada tanggal 12 Desember 2012] Diunduh dari: https://afriazenifatma94.wordpress.com/2012/12/12/perawatan-luka operasi/

13. Tim Redaksi iso indonesia. Redaksi iso indonesia vol.47 tahun 2012-2013. Jakarta: PT. ISFI; 2012.

14. Kapten. Tindakan Septik. [diakses pada tanggal 29 Maret 2013] Diunduh dari: http://bedahminor.com/index/php/main/show_page/217 